$\underline{\underline{p}}=$

\title{
Precarious Employment in Present-Day Russia: Relevant Worker Profiles
}

\author{
Vyacheslav Nikolaevich Bobkov ${ }^{1,2}$, Yuri Gennadievich Odegov ${ }^{2}$, Valentina Vasilievna Pavlova ${ }^{2}$ \\ ${ }^{1}$ The Russian Academy of Sciences The Institute of Social and Economic Studies of Population, Nakhimovsky Av., 32, Moscow, 117218 , \\ Russia \\ ${ }^{2}$ Plekhanov Russian University of Economics, Stremyanny Lane, 36, Moscow, 117997, Russia \\ *Corresponding author E-mail: bobkov.v.n@bk.ru
}

\begin{abstract}
This paper provides a characterization of the essence of precarious employment. The author describes some of the key stages in the transformation of the employment sector. The paper shares the findings from a sociological study into precarious employment in a representative group. The author has explored some of the key parameters for the group and has fine-tuned a set of indicators of precarious employment and their quantitative values which identify particular aspects of precarious employment (Note 1), namely with a focus on: assessments of the level of being protected by the employment contract (employee evaluations of the terms and conditions of the employment contract and assessments of the extent to which the employer abides by them; assessments of the likelihood of being laid off; assessments of one's willingness to look for another job and the reasons behind it); assessments of the accessibility of mechanisms of social protection for employees; self-assessments of material well-being; work conditions (e.g., length of the work week, half-time work, and availability and duration of work in an additional place); etc. The author has identified a total of 5 profiles for present-day employment in Russia, which are characterized by an increase in signs of precarious employment, and provides a comparative characterization thereof.
\end{abstract}

Keywords: precarious employment, labor market, standard of living, sociological survey of employees, contractual relationship, worker profiles, gender inequality, age inequality, educational inequality, self-esteem of precarious workers

\section{Introduction}

The paper shares the findings from a sociological analysis of present-day employment in Russia. The work is aimed at expanding the sociological instrumentarium for the study of precarious employment and use of sociological indicators to identify groups of workers within the context of precarious employment and verify economic and sociological indicators that characterize it.

\section{Theory}

A study of the economic/sociological genesis of the term 'precarity of employment' (hereinafter 'precarious employment') has shown that it is a product of the conceptualization of transformations that have taken place in terms of production forces and capitalist production relationships starting in the second half of the $20^{\text {th }}$ century. This has been reflected in the laying down of ground-work for a particular set of values. In the 1990s, these values became known as the "European Social Model". Among its key foundations are steady work and social guarantees: openended employment contracts and high levels of protection for the worker. In the USSR and Soviet Russia, workers were provided with more extensive job guarantees. The impact of the Soviet Union on the formation of the European Social Model in the 1950-1980s was significant. The period's major socially oriented transformations in Western Europe would, eventually, help shape the essence of the term 'standard employment'.
The first stage in the development of precarious employment is associated with accelerated modernization and capital advancing upon standard employment in Western Europe in the late 1980s and the 1990s. During that period, social linkages formed in the 1950-1980s, which helped smooth over social conflicts Western European countries, became disrupted. The outcomes of the scientific/technical revolution witnessed in the middle of the 20th century helped capital respond to the challenges of elevated social justice and economic well-being among the working class and left movements with growth in productivity and the formation of a flexible labor market and launch the process of large-scale restructurization of employment relationships. With employment starting to change from stable to unstable, there emerged a new mass phenomenon - so-called "precarious employment" (Note 2), with the term 'precarious' synonymous with being unreliable, dubious, and dangerous and the whole concept viewed as a threat to steady employment.

Capitalist globalization, which developed widely during the 1990s as a consequence of stiffening competition, including for cheap labor, augmented the chaotic and uncertain character of world development. Precarious employment not only was evolving on a wide international scale but also received a more adequate environment for its development. The world witnessed giant spikes in the migration of international capital and labor migration. In that climate, the global elite, i.e. global players in the markets for capital, got to face a lot fewer restrictions than the majority of people living, working, and acting within the framework of traditional national institutions [1]. Globalization facilitated the extension of the impact of precarious employment to societies, causing them to become less secure. Thus, insecurity 
spread beyond employment to affect the actual social systems throughout the world.

The above period has been covered extensively in foreign research into the essence, forms, and social implications of precarious employment. A considerable contribution to the development of its conceptual foundations and effect on stability in society has been made by Z. Bauman [2], U. Beck [3], L. Boltanski, E. Chiapello [4], L.F. Vosko [5], A.L. Kalleberg [6], R.-D. Hepp [7], P. Herrmann [8], G. Standing [9], R. Sennett [1, 10], W. Eichhorst, V. Tobsch [11], D. Grimshaw, M. Johnson, J. Rubery, A. Keizer [12], and others. The dominant theme across these publications is the search for solutions for improving the quality of public systems and adapting them to new conditions against a backdrop of the actual internal discrepancies in the development of capitalist globalization and the proposal of relevant corrective measures in keeping with the requirements for growth quality.

Having integrated international research on and gained a sufficient insight into the concept of precarious employment, the International Labour Organization (ILO) has formulated quite an extensive and credible theoretical platform of criteria for it, which is outlined below.

A. By type of contractual agreements:

I. Limited-term contracts (fixed-term contracts, short-term contracts, or contracts for temporary, seasonal, by-the-day, or occasional work);

II. Nature of employment relationships (not overt but multifaceted and covert employment relationships, fictitious (fake) selfemployment, subcontracts, and agency contracts).

B. Precarious employment conditions:

1) low pay;

2) poor protection from termination of the employment relationship;

3) lack of access to mechanisms of social protection and benefits that are traditionally associated with standard employment;

4) workers faced with limitations with regard to realization of their rights on the job [13].

This classification has been in wide use among members of the international community of researchers and practicians by reference to the national characteristics of specific regions.

In Russia, the development and conceptualization of the area of precarious employment began much later than overseas. This is due to the following characteristics of development in Russia:

1) in the USSR and Soviet Russia, precarious employment did not and could not exist as a mass phenomenon;

2) In the $1990 \mathrm{~s}$ and the first decade of the $21^{\text {st }}$ century, precarious employment represented a sizable segment of the Russian economy. However, the period is characterized by a known degree of euphoria and hype over Russia's return to the "course of development of world civilization", i.e. back into the fold of modern capitalism. This, along with the emergence of sponsors of research, who profited from that kind of transformations, led to the prevalence in the 1990s of research devoted to the effect of scientific/technical progress and new forms of work organization on employment. The focus was on investigating new organizational forms of employment. Subjected to quite thorough analysis were so-called "new" forms of employment, like nonstandard employment, flexible employment, and some of its other aspects associated with the rapid development of flexibility in the labor market $[14,15,16,17]$.

Social/economic characterizations of modern global capitalism, the unstable forms of employment, and high social differentiation have long been in the shadow of mainstream research into the economics and sociology of employment. There has been a paucity of research insights on infringement by capital and Russia's "liberal", in essence plutocratic, government, which serviced its interests, on the employment and social rights of workers Bizyukov, Lyapin, Shershukova, \& Neunhöffer [17], Bobkov [18], Buzgalin \& Kolganov [19], Subetto [20]. The social/economic aspect of the implications for workers of the development of flexibility in the labor market has been the subject of interest for Russian researchers mainly since the start of the second decade of the $21^{\text {st }}$ century.

In this period, a major contribution to the development of the subject of transformations in employment, as well as precarious employment in Russia, has been made by scholars P.V. Bizyukov [21], V.N. Bobkov, V.G. Kvachev, I.V. Novikova [22], O.V. Veredyuk, R.P. Kolosova, T.O. Razumova [23], E.A. Chernykh, U.T. Aliev, E.N. Kuril'chenko [24], Z.T. Golenkova, Goliusova [25], L.V. Sankova [26], T.Yu. Sidorina [27], Zh.T. Toshchenko [28], O.I. Shkaratan, V.V. Karacharovskii, E.N. Gasyukova [17], O.V. Sinyavskaya [29], and others.

Russia's conditions for a transition to the modern labor market are totally different from those in other countries. The Russian labor market, which formed against a backdrop of the breakup of the Soviet Union, continues today to experience the lingering effects of the Soviet planned economy, which had shaped the consciousness of many of the Russian people. Currently, Russia is going through the formation and development of a model of employment that is totally new to it. Due to this, the Russian labor market and employment sector are characterized by a large number of features that distinguish them from the labor market and employment practices in countries which, unlike Russia, have been guided by market-based relationships in transiting from less to more developed social/economic formations (civilizations).

The author is of the view that the second decade of the $21^{\text {st }}$ century marks the beginning of the second stage in the transformation of precarious employment as a global phenomenon. This, above all, is due to a scientific/technical revolution in the era of post-industrial capitalism (the late $20^{\text {th }}$ early $21^{\text {st }}$ century). It is leading to the rapid development of computerization, 3D technology, robotics, and other cutting-edge means and objects of production and new types of technology. Mankind is witnessing immense transformations with regard to requirements to workers, which is a consequence of its renunciation of traditional types of activity in the spheres of services, sales, management, and administrative work and changes in the essence and forms of employment in the areas of education, jurisprudence, communications, art, and mass media. Governments and national communities will have to come up with mechanisms for boosting the competitiveness of workers in a climate of flexible employment, ensuring protection for their less competitive counterparts, and reacting properly to uncertainty and instability in national development, which are due to capitalist globalization [30, 31].

Russia is entering this new stage in the development of flexible employment and its unstable forms in reliance on the rich international experience in resolving issues related to and some domestic experience with precarious employment, and is doing so as an active geopolitical subject of international relations.

This is a basis that is creating the preconditions for reducing the scale of precarious employment. However, no matter if those in charge want it or not, Russian capitalism has yet to throw off its "predatory" and plutocratic face, and the nation has yet to rid itself of dependence on raw materials and put an end to lags in the development of a whole array of innovative sectors. If existing conditions persist, growth in the role of the Russian national state in influencing processes of precarious employment may lead to an exacerbation of existing problems and greater insecurity in Russian society.

The purpose of this publication is to investigate precarious employment using a set of sociological indicators. The study object is to provide a characterization of precarious employment as a whole across worker population and determine a set of relevant worker profiles. The study's hypothesis is that, depending on the type of contractual relationships and how well their terms are observed, most worker profiles will differ in workers' social/demographic, age-related, education-related, and economic characteristics. 


\section{Methods and data}

The designated research method was a mass Internet-based survey conducted via a special online-platform. The survey was conducted September 13 through 29, 2016, using a special questionnaire. The sample was quota-controlled by gender, age, place of residence (across the federal okrugs), and status in the labor market and selected in proportion to the general population (based on data from Rosstat).

The author analyzed a common array of those employed officially and unofficially, wage-earning and self-employed (678 respondents), who accounted for $67.7 \%$ of the overall number of respondents. The group included respondents who, when asked about their status in the labor market, responded they "worked for hire (including "off work sick/on vacation)/were self-employed" and "worked for hire off the books/were self-employed unofficially, with no legal registration".

The survey helped explore some of the key parameters for the above group and fine-tune a set of indicators of precarious employment and their quantitative values which identified particular aspects of precarious employment (Note 1)

At the second stage, the author employed the grouping method to divide the group under study into 5 profiles. This division was grounded in the criterion of the type of contractual relationships and how well they were abided by.

By type of contractual agreements, the author identified 4 groups of workers: 1) workers satisfied with their employment - those employed via an official overt open-ended contract and those employed via a close-ended contract with a length of 1 year and up (200 respondents); 2) workers with open-ended employment contracts and with close-ended contracts with a length of one year and up who were not satisfied with their employment conditions and the way the employer observed the terms of the employment contract; 3) workers employed in an unstable manner: those employed on a fictitious self-employment, subcontract, agency contract basis, but employed via an official contract; 4) workers employed within the shadow sector of the economy.

Initially, the first group of workers was formed from individuals in standard employment (Group 1) with a high degree of protection provided by the employment agreement with regard to worker rights and guarantees and a high degree of observation of the terms of the employment agreement on the part of the employer (100\% of all workers). The rest of the groups $(2-4)$ were formed in accordance with decrease in the extent of these characteristics of employment and increase in the degree to which employment rights were infringed on or workers were vulnerable in the employment relationship, inclusive of minor or major violations of the terms of the employment agreement. In Groups 2 and 3, these characteristics were $80.2 \%$ and $74.7 \%$ and $97.3 \%$ and $93.5 \%$, respectively. In Group 4, which included those employed in the shadow economy, negative indicator values initially were $100 \%$. Negative indicator values in Groups 2-4 exceeded the level across all workers overall (41\% and $38 \%)$.

Based on these characteristics of contractual arrangements, the author formed 4 major profiles of respondents characterized by escalating precarious employment (Note 3). The 4 profiles of workers, identified based on type of contractual relationships, were numbered in order from the lowest to highest degree of precarious employment, as follows below.

Profile 1 - workers with the greatest indicators of standard employment. These are wage and salary workers, satisfied with their employment, who are either employed via official overt open-ended contracts or via close-ended contracts with a length of 1 year and up (200 respondents)

Profile 2 - wage and salary workers with official contracts who are not satisfied with their employment from a standpoint of the way their rights are protected by the employment agreement and/or the way the employer abides by the terms of that agreement (273 respondents).
Profile 3 - workers employed in an unstable manner who have official contracts (employed on a fictitious self-employment, subcontract, agency contract basis, etc.) (192 respondents).

Profile 4 - workers characterized by the greatest degree of precarious employment. These are informally employed workers (individuals employed via an unofficial ("shadow") employment agreement with an employer or unregistered sole entrepreneurs (102 respondents).

To provide a characterization of low-paid workers, the author formed a separate, 5 th, profile for precariously employed workers.

Profile 5 was put together in order to characterize indicators of precarious employment with low-paid workers, regardless of the nature of contractual relationships. It included workers with an income below two-thirds of median income across Russia $(15,000$ rubles) (126 respondents).

\section{Results}

The study helped identify a set of substantial characteristics of the worker profiles, with different combinations of the manifestation of stable and precarious employment:

Profile 1. This profile included workers in standard employment. Their characteristics differed from those of the rest significantly. This group was distinguished by a large share of females $(61 \%$; $46 \%$ across all workers overall); a large share of individuals in their older working and retirement years $(74.5 \% ; 24.3 \%$ across all workers overall); an insignificant share of youth $(6.5 \% ; 25.7 \%$ across all workers overall); a large share of workers with higher vocational education $(71.5 \%$; $63 \%$ across all workers overall); most working a standard working week $(53 \%$; $43 \%$ across all workers overall); the lowest levels of incomplete and excessive employment (19\% and 28\%; 22 and $35 \%$ across all workers overall); higher level of income from employment (the share of the lowest-paid workers (with an income below the living wage) was $4.6 \% ; 8.8 \%$ across all workers overall), although, on the whole, their distribution by level of income did not differ too much from that with workers from the rest of the profiles); the lowest relative share of workers whose rights were infringed on and whose access to mechanisms of social protection was limited, although there were elements of unstable employment in a climate of standard employment as well; better self-assessments of one's material status. Most workers in this profile selected Positions 3 and 4 on the self-assessment scale $(84 \% ; 79.1 \%$ across all workers overall); the lowest likelihood of getting laid off within one year on the job was identified here. The average and high values for the likelihood of getting laid off (Positions 3-5) within one year on the job were from $1 \%$ to $10 \%$ (from $5 \%$ to $15 \%$ across all workers overall); the group was also distinguished by the lowest relative share of those already employed who continued looking for a job $(35.5 \% ; 56 \%$ across all workers overall).

There is a need to come up with ways to ease entry into this profile for males, youth, and individuals in their prime working years (30-50 years of age) to ensure that this segment of standard employment can demonstrate its definite advantages in a climate of gender equality in employment, as well as for workers of all ages. One will also have to answer the question of whether contracted reproduction is the result of shortcomings in the management of employment or an objective trend that is governed by the development of flexible forms of employment.

Profile 2. Workers in this profile differed from those in Profile 1 in that there was an escalation in precarious employment due to the employer breaching the terms of the employment agreement, with these terms being misaligned with the actual employment relationships and workers, consequently, being dissatisfied with their employment $(65.9 \%$ said the agreement provided insufficient protection for their employment rights, while $23.1 \%$ said their rights provided for under the agreement were respected in a fair manner; across all workers overall the figures were $34 \%$ and $60 \%$ ). On the whole, no major differences from the employment 
conditions of workers in Profile 1 were recorded here. This profile exhibited an increase in the share of males $(48 \%$; $46 \%$ across all workers overall); a greater share of youth and individuals in their prime working years (30-50 years of age) $(24.5 \%$ and $49.5 \%$; $25.7 \%$ and $50 \%$ across all workers overall); a decline in the share of workers with higher vocational education and an increase in the share of workers with secondary vocational education $(65.2 \%$; $63 \%$ across all workers overall); a decline in the share of workers working a standard working week $(44 \% ; 43 \%$ across all workers overall); greater employment flexibility (the levels of incomplete and excessive employment were $16.3 \%$ and $38.8 \% ; 22 \%$ and $35 \%$ across all workers overall); a greater share of workers with low income from employment (the share of workers with an income below the living wage was $9.6 \% ; 8.8 \%$ across all workers overall); an increase in the relative share of workers whose rights were infringed on and whose access to mechanisms of social protection was limited, although these values were lower here than across all workers overall (nonpayment of taxes and insurance - 5.1\%, nonpaid sick leaves $-6.6 \%$, nonpaid vacations $-5.5 \%$; across all workers overall the figures were $12 \%, 15 \%$, and $15.6 \%$ ); lower self-assessments of one's material status $(77.7 \%$ rated it at 3 and 4 on the assessment scale; $79.1 \%$ across all workers overall); a greater likelihood of getting laid off within just one year on the job. The average and high values for the likelihood of being laid off (Positions 3-5) within one year on the job were from $8.4 \%$ to $14.7 \%$ (5\% to $15 \%$ across all workers overall). However, all of these, at first glance not-too-major, trends toward greater indicators of precarious employment were reflected in that the relative share of those already employed who continued looking for a job increased tangibly $(64.5 \%$; $56 \%$ across all workers overall). This figure was almost twice that with workers in Profile 1.

There is a need to come up with answers to a whole array of questions, like whether or not greater indicators of precarious employment with workers in Profile 2 are the result of negligence on the part of the employer and insufficient control over the employer's activity on the part of the authorities? If the answer is 'yes', it may be possible to overcome this. Conversely, is the price to pay for an expansion of the share of youth and individuals in their prime working years within this profile a decline in the relative share of those working a standard working week, greater employment flexibility, a greater need and potential for the employer to mitigate the requirements for the employment agreement, with greater employee turnover and greater indicators of precarious employment resulting from that? Perhaps, it could be both. It is answers to these questions that will shape potential transformations of employment legislation and the future image of Profile 2.

Profile 3. Changes in the nature of employment for workers in this profile are major. Compared with those in Profiles 1 and 2, this group was represented by workers employed through socalled "new" forms of employment. These were workers with official contracts and employed not via open-ended employment agreements or close-ended ones, but long-term contracts and in a precarious manner by way of telecommuting, on a subcontract, agency contract, or fictitious self-employment basis, via civil/legal agreements, and other new forms of employment.

In terms of their status, workers in Profile 3 differed from those in Profiles 1 and 2 not in their gender-, age-, and education-related characteristics, although these differences did exist and would later be described herein. The key differences consisted in: a) a sharp decline in the share of workers for whom the employment agreement ensured employment rights' protection and in respect of whom the employer had duly abided by its terms $(1.8 \%$ and $2.4 \% ; 46 \%$ and $60 \%$ across all workers overall; the figures were $12.5 \%$ and $23.1 \%$ with workers in Profile 2);

b) a considerable decline in the share of workers with a standardlength working week and an increase in work intensity as a result of a tangible increase in excess work (34.4\% and $47 \%$; $43 \%$ and
$35 \%$ across all workers overall; $44 \%$ and $38.8 \%$ with Profile 2 workers).

Profile 3 was characterized by the following indicators of employment. These workers were distinguished by the prevalence of males $(52 \%$; $46 \%$ across all workers overall); a large share of youth and individuals in their prime working years (30-50 years of age) $(27.1 \%$ and $49.5 \% ; 25.7 \%$ and $50 \%$ across all workers overall); a smaller share of workers with higher vocational education and a greater share of workers with secondary vocational education $(57.8 \% ; 63 \%$ across all workers overall); a greater share of workers with low income from employment (the share of workers with an income below the living wage was $12.56 \% ; 8.8 \%$ across all workers overall); a greater relative share of workers whose rights were infringed on and whose access to mechanisms of social protection was limited (nonpayment of taxes and insurance $-7.8 \%$, nonpaid sick leaves $-9.4 \%$, nonpaid vacations $-8.3 \%$; across all workers overall the figures were $12 \%$, $15 \%$, and $15.6 \%$ ); lower self-assessments of one's material status (75.5\% rated it at 3 and 4 on the assessment scale; $79.1 \%$ across all workers overall); greater likelihood of getting laid off within just one year on the job. The average and high values for the likelihood of being laid off (Positions 3-5) within one year on the job were from $9.4 \%$ to $19.8 \%$ (5\% to $15 \%$ across all workers overall). The trend toward an increase in indicators of precarious employment was reflected in that the relative share of those already employed who continued looking for a job increased tangibly $(73.4 \% ; 56 \%$ across all workers overall; Profile 2 workers had this indicator at $64.5 \%$ ).

To summarize the characteristics of contractual agreements and conditions of employment with workers in Profile 3, it is worth noting that Russia's current labor legislation is not well-tuned to regulating their employment in an effective manner. As a consequence, workers in Profile 3, more than others within the formal sector of the economy, get to face infringement on their employment and social rights and instability in employment. A relevant objective is to transform existing labor, civil, and other laws in an attempt to help ensure the observation of workers' employment and social rights in a climate of nonstandard and flexible employment, which is typical of the employment of workers in this profile.

Profile 4. What workers in this group have in common with those in Profile 3 in the formal economy is that both groups are employed in nonstandard, i.e., new forms of employment. The difference is that workers in Profile 4 are employed in the shadow economy. From the outset, this means infringing on the major employment and social rights and condemns them to precarious employment. In this regard, it is worth responding to the question - Why does it continue to grow, even though the federal and municipal authorities have taken a plethora of measures to get this employment out of the "shadows"?

In the author's view, it is the development of nonstandard forms of employment (which is an objective process) that has been behind this, with the government having yet to learn how to secure the employment and social rights of workers in the formal (legal) economy, including new flexible forms of employment. This was demonstrated above when talking about the economic and social status of workers in Profile 3. Under these conditions, employment in the shadow economy, despite being forced, appears to often be more attractive to workers and employers. Based on the findings from the author's survey, in making a decision workers are normally guided by the following considerations.

Firstly, in terms of employment conditions, workers within Profile 4 exhibited lower levels of poverty $(9.07 \% ; 8.76 \%$ across all workers overall; the figure was the highest with workers within Profile $3-12.56 \%$ ). The ability of employers within Profile 4 to avoid paying income tax and making insurance payments enabled them to ensure greater pay for workers and minimize poverty. Secondly, the flexibility of employment with workers within this profile was reflected not only in a significant decrease in the 
standard length of a working week $(25.9 \%$; $43 \%$ across all workers overall) but also in the high share of workers with a shortened working week $(37.9 \% ; 22 \%$ across all workers overall; $18.2 \%$ with Profile 3 workers). The latter had to overwork more (47\%; 36.2\% in Profile 3). Apparently, it was not for no reason that among this profile's workers many had general and complete secondary education $(18.6 \%$, with their relative share across all workers overall being $7.5 \%$ and $4.7 \%$ within Profile 3 ). Thus, young workers within the younger age group appear to have found in the shadow economy a niche for its employment, as flexible part-time employment could enable them to continue schoolwork and, also, actualize some of their other life plans. It is no wonder that the relative share of youth in this profile was the highest $(28.4 \% ; 25.7 \%$ across all workers overall; $27.1 \%$ within Profile 3$)$ (the forms of employment were flexible there too).

Thirdly, the likelihood of Profile 4 workers getting laid within the first year on the job had lower values versus workers within Profile 3 (from $3.9 \%$ to $14.7 \%$; between $5 \%$ and $15 \%$ across all workers overall; the value was tangibly higher with workers within Profile 3 - between 9.4\% and 19.8\%). The relative share of Profile 4 workers looking for a job while having one was lower than that of workers within Profile $3(65 \% ; 56 \%$ across all workers overall; $73.4 \%$ with workers within Profile 3 ).

Profile 4 exhibited the following characteristics with regard to the status of workers. It had the highest share of males $(53 \% ; 46 \%$ across all workers overall), the highest share of youth $(28.7 \%$; $25.7 \%$ across all workers overall), the highest share of workers with secondary (complete) general education $(18.6 \% ; 6.8 \%$ across all workers overall), the lowest share of workers with higher vocational education $(45.1 \%$, across all workers overall $-63 \%)$, high share of workers with low income $(22.4 \% ; 8.8 \%$ across all workers overall). $43 \%$ of those within this profile refused to share information about their income from employment.

The author believes it is possible for workers and employers within Profile 4 to come out of the "shadows". To help achieve this, the government needs to focus on resolving issues of protection of the employment and social rights of workers in nonstandard employment in the formal economy and, especially, workers in nonstandard employment within Profile 3. Otherwise, vice versa, the scale of informal employment is going to expand.

Profile 5. Workers within this profile were gathered from the rest of the profiles based on the low-paid employment attribute. The distinctive characteristics for this group included: gender lopsidedness $-71 \%$ being females $(53 \%$ across all workers overall); a higher relative share of youth $-32.5 \%$ (25.7\% across all workers overall), and of individuals within the older age group (60-72 years) $-12.7 \%$ (5.3\% across all workers overall); the highest relative share of workers with secondary (complete) general education $-9.5 \%$ (6.8\% across all workers overall); a lower relative share of workers with higher vocational education $52.4 \%$ (63\% across all workers overall). $44 \%$ of this group's workers had an income below the living wage for the employable population (8.8\% across all workers overall).

\section{Conclusion}

The fact that many workers are shifting today from stable to precarious employment is having quite a profound transforming effect on Russia's present-day labor market. This is clearly evidenced by the differences in social/demographic, social/labor, and economic characteristics between workers subsumed under Profiles 2-4 and those in Profile 1 who are in standard employment with, likewise, elements of precariousness. The identified attributes of precarious employment, their characteristics in each of the formed profiles of workers, and the differences in their demographic, age-related, education-related, and economic characteristics require conceptualizing and making appropriate decisions to limit precarious employment.

\section{Acknowledgements}

The research reported in this paper was supported by Grant No. 16-1810140 from the Russian Science Foundation.

\section{Notes:}

1. These parameters were put together based on an analysis of the essence of the concept of precarious employment, as well as based on the findings from some of the research conducted by the author and his colleagues $[27,28]$

2. The term is derived from the Latin word 'precarius', which means "obtained by entreaty or by mere favor".

3. Growth in precarious employment is characterized by the number and size of indicators that describe it.

\section{References}

[1] R. Sennett, The corrosion of character: The personal consequences of work in the new capitalism, W. W. Norton, New York, 1998.

[2] Z. Bauman, Individualizirovannoe obshchestvo [The individualized society] (V. L. Inozemtsev, Trans.), Logos, Moscow, 2005.

[3] U. Beck, The brave new world of work, Polity Press, Cambridge, 2000 .

[4] L. Boltanski, E. Chiapello, Novyi dukh kapitalizma [The new spirit of capitalism], (N. Savel'eva \& O. Zhuravlev, Trans.), Novoe Literaturnoe Obozrenie, Moscow, 2011.

[5] L. F. Vosko, Precarious employment: Towards an improved understanding of labour market insecurity, Precarious employment: Understanding labour market insecurity in Canada, McGill-Queen's University Press, Montreal, 2006, 3-39.

[6] A. L. Kalleberg, Precarious work, insecure workers: Employment relations in transition, American Sociological Review 74(1) (2009) $1-22$.

[7] R.D. Hepp, Prekarisierung und Flexibilisierung, Westfälisches Dampfboot, Münster, 2012.

[8] P. Herrmann, S. Kalaycioglu, Precarity: More than a challenge of social security. Or: Cynicism of EU's concept of economic freedom, Hochschulverlag GmbH \& Co. KG, Bremen, 2011.

[9] G. Standing, Prekariat: novyi opasnyi klass [The precariat: The new dangerous class] (N. Usova, Trans.), Ad Marginem, Moscow, 2014.

[10] R. Sennett, The culture of the new capitalism, Yale University Press, New Haven, CT, 2006.

[11] W. Eichhorst, V. Tobsch, Risk of precarious work in the public sector. European Parliament http://www.europarl.europa.eu/RegData/etudes/BRIE/2017/602025 /IPOL_BRI(2017)602025_EN.pdf Revised March 2017

[12] D. Grimshaw, M. Johnson, J. Rubery, et al., Reducing precarious work: Protective gaps and the role of social dialogue in Europe. http://www.research.mbs.ac.uk/ewerc/Portals/0/Documents/Compar ative-Report-Reducing-Precarious-Work-v2.pdf Revised November 2016

[13] International Labour Office. Decent work indicators: Concepts and definitions. https://ru.scribd.com/document/137359758/DecentWork-Indicators-Concepts-and-definitions Revised May 2012

[14] V. E. Gimpel'son, R. I. Kapelyushnikov, Nestandartnaya zanyatost' $i$ rossiiskii rynok truda [Precarious employment' and the Russian labor market], GU VShE, Moscow, 2005.

[15] R. I. Kapelyushnikov, Nestandartnye formy zanyatosti $i$ bezrabotitsy $v$ Rossii [Nonstandard forms of employment and unemployment in Russia], GU VShE, Moscow, 2004.

[16] R. P. Kolosova, T. O. Razumova, M. V. Ludanik, Formy zanyatosti naseleniya $v$ innovatsionnoi ekonomike: Uchebnoe posobie [Forms of employment for the population in an innovation-driven economy: A study guide], MAKS Press, Moscow, 2008.

[17] O. I. Shkaratan, V. V. Karacharovskii, E. N. Gasyukova, Prekariat: Teoriya i empiricheskii analiz (na materialakh oprosov v Rossii, 1994-2013) [The precariat: Theory and empirical analysis (based on the findings from surveys conducted in Russia between 1994 and 2013)], Sotsiologicheskie Issledovaniya 12 (2015) 99-110.

[18] P. Bizyukov, A. Lyapin, L. Shershukova, et al., Neustoichivaya zanyatost' $i$ ee posledstviya dlya rabotnikov [Precarious employment and its implications for workers], ANO Tsentr Sotsial'no-Trudovykh Prav, Moscow, 2007. 
[19] V. N. Bobkov, Uroven' i kachestvo zhizni naseleniya v sovremennoi Rossii [People's standard of living and quality of life in present-day Russia], VTsUZh, Moscow, 2007.

[20] A.V. Buzgalin, A. I. Kolganov, Global'nyi kapital [Global capital], Editorial URSS, Moscow, 2004.

[21] I. Subetto, Kritika "ekonomicheskogo razuma": Nauchnaya monografiya [A criticism of the "economic mind": A research monograph], KGU im. N.A. Nekrasova, Kostroma, (2008).

[22] P. V. Bizyukov, Praktiki regulirovaniya trudovykh otnoshenii v usloviyakh neustoichivoi zanyatosti [Practices in regulating labor relations in a climate of precarious employment], ANO Tsentr Sotsial'no-Trudovykh Prav, Moscow, 2013.

[23] V. N. Bobkov, V. G. Kvachev, I. V. Novikova, Neustoichivaya zanyatost' $v$ regionakh Rossiiskoi Federatsii: Rezul'taty sotsiologicheskogo issledovaniya [Precarious employment in the regions of the Russian Federation: The findings from a sociological study], Ekonomika Regiona 14(2) (2018) 366-379.

[24] V. N. Bobkov, O. V. Veredyuk, R. P. Kolosova, et al., Zanyatost' $i$ sotsial'naya prekarizatsiya $v$ Rossii: Vvedenie $\mathrm{V}$ analiz [Employment and social precarization in Russia: An introduction to its analysis], TEIS, Moscow, 2014.

[25] V. N. Bobkov, E. A. Chernykh, U. T. Aliev, et al., Neustoichivost' zanyatosti: Negativnye storony sovremennykh sotsial'no trudovykh otnoshenii. [Precarious employment: Negative aspects of presentday social/labor relations], Uroven' Zhizni Naseleniya Regionov Rossii 5 (2011) 13-25.

[26] Z. T. Golenkova, Yu. V. Goliusova, Rossiiskii prekariat: Problemy nakopleniya chelovecheskogo kapitala [The Russian precariat: Issues surrounding the accumulation of human capital], Vestnik Instituta Sotsiologii 3 (2016) 57-69.

[27] L. V. Sankova, Prekarizatsiya zanyatosti V sovremennoi ekonomike: Sistemnyi risk ili «osobaya» forma fleksibilizatsii [Precarization of employment in the present-day economy: A systemic risk or a "special" form of flexibilization?], Uroven' Zhizni Naseleniya Regionov Rossii 4 (2014) 44-53.

[28] T. Yu. Sidorina, Tsivilizatsiya truda: Zametki sotsial'nogo teoretika [Civilization of work: Notes by a social theoretician], Aleteiya, Saint Petersburg, 2014

[29] Zh. T. Toshchenko, Prekariat - novyi sotsial'nyi klass [The precariat - a new social class], Sotsiologicheskie Issledovaniya 6 (2015) 3-13.

[30] O. V. Sinyavskaya, Neformal'naya zanyatost'v sovremennoi Rossii: Izmerenie, masshtaby, dinamika [Informal employment in presentday Russia: Measuring it, its scale, and its dynamics], Pomatur, Moscow, (2005)

[31] International Labour Office. From precarious work to decent work Outcome document to the Workers' Symposium on Policies and Regulations to Combat Precarious Work http://www.ilo.org/wcmsp5/groups/public/---ed_dialogue/--actrav/documents/meetingdocument/wcms_179787.pdf Revised 2012.

[32] International Labour Office. Meeting the challenge of precarious work: A workers' agenda. International Journal of Labour Research 5(13) 2013. http://www.ilo.org/actrav/info/internationaljournal-labour-research/WCMS_216282/lang--en/index.htm Revised June 2013. 